\title{
CRITICAL SUCCESS FACTORS FOR BROWN-FIELD CAPITAL AND RENEWAL PROJECTS
}

\author{
J. Warchol ${ }^{1}$ and J. Amadi-Echendu ${ }^{2}$ \\ 2 Department of Engineering and Technology Management, \\ University of Pretoria, South Africa. \\ joe.amadi-echendu@up.ac.za
}

\begin{abstract}
Manufacturing companies operate in a business environment where incremental growth may be achieved through expansion and renewal of existing plant and facilities. Effective management of the critical success factors of such capital development projects may also provide competitive advantage. These projects tend to be of a brown-field nature, characterised by a significant level of risk arising from the interaction between the project implementation and concurrent operation of the existing physical asset base. So it is vital to understand the factors that influence the success of capital expansion and renewal projects in the brown-field context. Although each project has unique features, there are critical success factors that can be customised for successful outcomes in the brown-field environment. This study identifies five critical success factors applicable to brown-field capital expansion and renewal projects. Managerial focus on the critical factors, and the prospects for successful brown-field projects, are discussed in the paper.
\end{abstract}

\section{OPSOMMING}

Vervaardigers funksioneer in 'n sakeomgewing waar voortgesette groei bereik word via uitbreiding en hernuwing van bestaande fasiliteite. Die doeltreffende bestuur van kritiese suksesfaktore van sodanige kapitaalprojekte bied geleentheid vir mededingende voordeel. Projekte van hierdie aard neig om geklassifiseer te word as van herontwikkelingsaard, met betekenisvolle gepaardgaande risiko wat voortspruit uit die interaksie tussen projekimplementering en gelyktydige bedryf van bestaande fisiese bates. Derhalwe is dit belangrik om in die konteks van herontwikkeling aandag te gee aan die kritiese faktore wat ' $n$ rol speel in die bereiking van sukses. Die navorsing identifiseer vyf kritiese suksesfaktore van belang vir uitbreidings- en vernuwingsprojekte.

\footnotetext{
${ }^{1}$ This author was enrolled for the M Eng (Project Management) Degree at the University of Pretoria.
} 


\section{INTRODUCTION}

Project management is a well-structured discipline that offers approaches that may be applied to almost any activity or aspect of human life, spanning cultures, industries, and organisations. Project management evolves all the time in order to accommodate the latest requirements demanded by new circumstances, or by social or technological developments. It seems obvious that manufacturing companies can increase their market share through the successful execution of capital development projects. The market environment of the $21^{\text {st }}$ century demands high quality products within an acceptable price range and delivered in the shortest possible time. As a result, organisations must continually improve the quality of their products and the efficiency of their processes to remain competitive. In many cases, organic growth of an existing physical asset base may be essential to gaining competitive advantage. A strategically planned and executed portfolio of capital expansion and renewal projects may be vital to creating economic value and maintaining competitive advantage.

Manufacturing companies operate within very specific business dynamics that require a focus on sustained growth. These companies tend to increase their competitiveness through unit cost reductions and compliance with quality, reliability, and delivery of product obligations rather than pricing. As a result, there is ongoing need within these organisations continually to improve their production facilities and processes. However, while growth provided by completely new plant facilities is not uncommon, the incremental growth of a manufacturing company may be the result of a revolving program of expansion and renewal of an existing physical asset base, which means that the majority of such projects tend to be of a brown-field nature.

A brown-field project is typically executed within, and usually at the mercy of, an existing plant and operational environment. Ongoing operations tend to impose a significant level of risk, causing, for example, scope and schedule changes. The management of an expansion or renewal project must not only ensure its efficient and effective implementation, but must also accommodate the business performance requirements for both new and existing physical assets. This concurrent requirement for successful project execution and sustained business performance is often difficult to achieve.

Ideally, project risk should be gradually mitigated during the project execution. To facilitate this process, it is essential to identify factors critical to the project success (critical success factors). By definition, every project is a unique endeavour subject to unique risks, and hence also to unique interrelationships between a given set of critical success factors. The available body of knowledge suggests that there may be a cluster of critical success factors for projects executed in a similar environment. The implication is that there is a specific set of critical success factors for brownfield projects. Therefore, management efforts should be focused on such a cluster of critical factors to increase the probability of project success.

Previous experience indicates the need to customise a cluster of critical success factors to address the practicalities in the execution of brown-field expansion and 
renewal projects. Above all, it is necessary to identify and manage the critical factors on an ongoing basis in order to improve the chance of project success. Unfortunately, there is little information in the public domain regarding the cluster of critical success factors for brown-field expansion and renewal projects. Furthermore, the extent to which managerial focus on the critical factors improves the success rate of brown-field projects is not readily discernible.

The objectives of the study described in this paper are to:

(i) identify critical success factors specific to brown-field projects, and

(ii) establish the correlation between management focus on critical factors and project outcome.

This study examines the following two questions:

- What factors are critical to successful brown-field projects?

- What is the correlation between managerial focus (effort) on the critical factors and the overall outcome (success) for brown-field construction projects?

The questions also lead to two hypotheses:

- H1: There exists a set of critical success factors for brown-field projects.

- H2: Increased managerial focus on the critical factors increases the chance of project success.

\section{THEORETICAL BACKGROUND}

Project management draws from the precedence network diagramming techniques developed for the Polaris Submarine project in the 1950s (Fondahl [8]). Today, virtually all construction, product development and engineering efforts use some formal project management approach (Cleland and King, [5]). There is seemingly no common definition for project management. Oisen [10] defines project management as "a collection of tools and techniques ... to direct the use of diverse resources toward the accomplishment of a unique, complex one-time task within time, cost and quality constraints”.

For many companies, executing a strategically-planned portfolio of successful projects is necessary to sustain long-term growth (Bloodgood and Katz, [4], p.60). Thus, defining and assessing project success is a strategic management imperative (Shenhar et al. [14]). Cost, time, and quality are measures that have become inextricably linked over the last 50 years with project success. Atkinson ([1], p.339) proposes assessment in two categories:

- measures of success during project implementation (“doing it right”), such as cost, time, and quality, and

- criteria for success following project execution ("getting it right”), which include impact on customer business outcomes resulting from the project, and how well the project prepares the organisation for the future. 
Other researchers generally support this line of thinking. Shenhar et al. [14] identified four success dimensions:

(i) project efficiency,

(ii) impact on the customer,

(iii) direct business and organisational success, and

(iv) preparing for the future.

A survey by White and Fortune [17] indicated that, even though most of the respondents measured project success in terms of time, budget, and specification, they were also concerned with the impact of the project on the organisation involved. Some studies suggest adding a new element to the notion of project success - client satisfaction (Lim and Mohamed, [9] and DeCotiis and Dyer, [6]). Baker and Fisher [2] went a step further by including the level of satisfaction of four different stakeholders: the customer, the developer, the project team, and the end user. Some researchers investigated the issue in the reverse manner, by studying the causes of project failure. Using this approach, Pinto and Mantel [11] identified three aspects of project performance as benchmarks for measuring the success or failure of a project: the implementation process, the perceived value of the project, and client satisfaction with the result.

Project success and failure were first introduced by Rubin and Seeling [13], with Shenhar et al. [14], Pinto and Mantel [11] reiterating that project success was contingent upon the specific project characteristics. Shultz, Slevin and Pinto [15] were among the first to classify the critical factors. Unfortunately, there is little agreement on the causal factors of project success (Pinto and Slevin, [12]). Belassi and Tukel [3] proposed that factors be grouped in four areas:

(i) those related to project,

(ii) those related to the project manager and the team,

(iii) those related to the organisation, and

(iv) those related to the external environment.

These groupings are interrelated: a factor in one group might influence a factor in another group (Dvir, Lipovetsky, Shenhar and Tischler [7], Belassi and Tukel [3], White and Fortune [17], and Westerveld [16]). Although each project is unique, similar types of projects may exhibit distinctive patterns of factors associated with success or failure (Pinto and Mantel [11]). While each project might require a different set of critical success factors, similar projects should have similar groups of critical success factors. It is therefore possible to define groups of success factors for any type of project. These groups of factors must thereafter be carefully managed throughout the project lifecycle to achieve success.

\section{RESEARCH}

The first purpose of the study was to identify a cluster of critical success factors applicable to brown-field expansion and renewal projects. The second purpose was to establish the relationship between managerial focus on these factors and project 
outcome. The set of applicable success factors was established, based on the selection and ranking of the most common factors as viewed by a judgemental sample population. Project success measures were established in a similar manner by surveying another sample population. Managerial focus on the identified set of critical success factors was evaluated by means of structured interviews conducted with key personnel involved in a selected group of projects. The correlation between the managerial focus on the critical success factors and the project outcome was thereafter established through the analysis of the collected data. Our study concentrated on three distinctive areas, each of them requiring its own process.

\subsection{Critical success factors}

Twenty factors were selected, based on a literature review. A survey questionnaire was used to test the perceptions of the project community with respect to the importance of each identified factor. Respondents were asked to rate the impact of each factor on both green-field and brown-field project environments, as well as to rank the importance of each factor for the success of brown-field construction projects. All success factors were subsequently ranked in terms of their importance and impact. The top five selected factors were those that the respondents considered to have more impact on brown-field projects.

Table 1 illustrates the selection process for the critical success factors. Column A indicates the perceived impact of the success factor, while column B indicates the perceived importance of each success factor for brown-field projects. The critical success factors are those that have the highest combined level of importance and impact.

\begin{tabular}{|l|c|c|c|c|c|c|}
\hline $\begin{array}{l}\text { Description of } \\
\text { success factor }\end{array}$ & $\begin{array}{c}\text { Higher } \\
\text { impact on } \\
\text { brown-field } \\
\text { project }\end{array}$ & $\begin{array}{c}\text { Impact } \\
\text { Rank } \\
\text { (a) }\end{array}$ & $\begin{array}{c}\text { Importance } \\
\text { indicator }\end{array}$ & $\begin{array}{c}\text { Importance } \\
\text { Rank } \\
\text { (b) }\end{array}$ & $\begin{array}{c}\text { Rank } \\
\text { Total } \\
\text { (a + b) }\end{array}$ & $\begin{array}{c}\text { Csf } \\
\text { Code }\end{array}$ \\
\hline $\begin{array}{l}\text { Consultation and } \\
\text { communication } \\
\text { with client }\end{array}$ & 37 & 4 & 144 & 3 & 7 & CSF 1 \\
\hline $\begin{array}{l}\text { Recognising } \\
\text { complexity }\end{array}$ & 44 & 1 & 127 & 10 & 11 & CSF 2 \\
\hline $\begin{array}{l}\text { Commitment of } \\
\text { end user }\end{array}$ & 39 & 3 & 130 & 9 & 12 & CSF 3 \\
\hline $\begin{array}{l}\text { Flexible approach } \\
\text { to change }\end{array}$ & 34 & 5 & 125 & 12 & 17 & CSF 4 \\
\hline $\begin{array}{l}\text { Taking account of } \\
\text { external influences }\end{array}$ & 41 & 2 & 115 & 17 & 19 & CSF 5 \\
\hline
\end{tabular}

Table 1: Identification of the critical success factors

The relationship between the responses of the three stakeholder groups was investigated to establish an acceptable level of confidence in the importance ranking of the critical success factors. Figure 1 shows reasonable agreement within 
respondent groups, even though the consultant group did not rank the factors at the same level of importance.

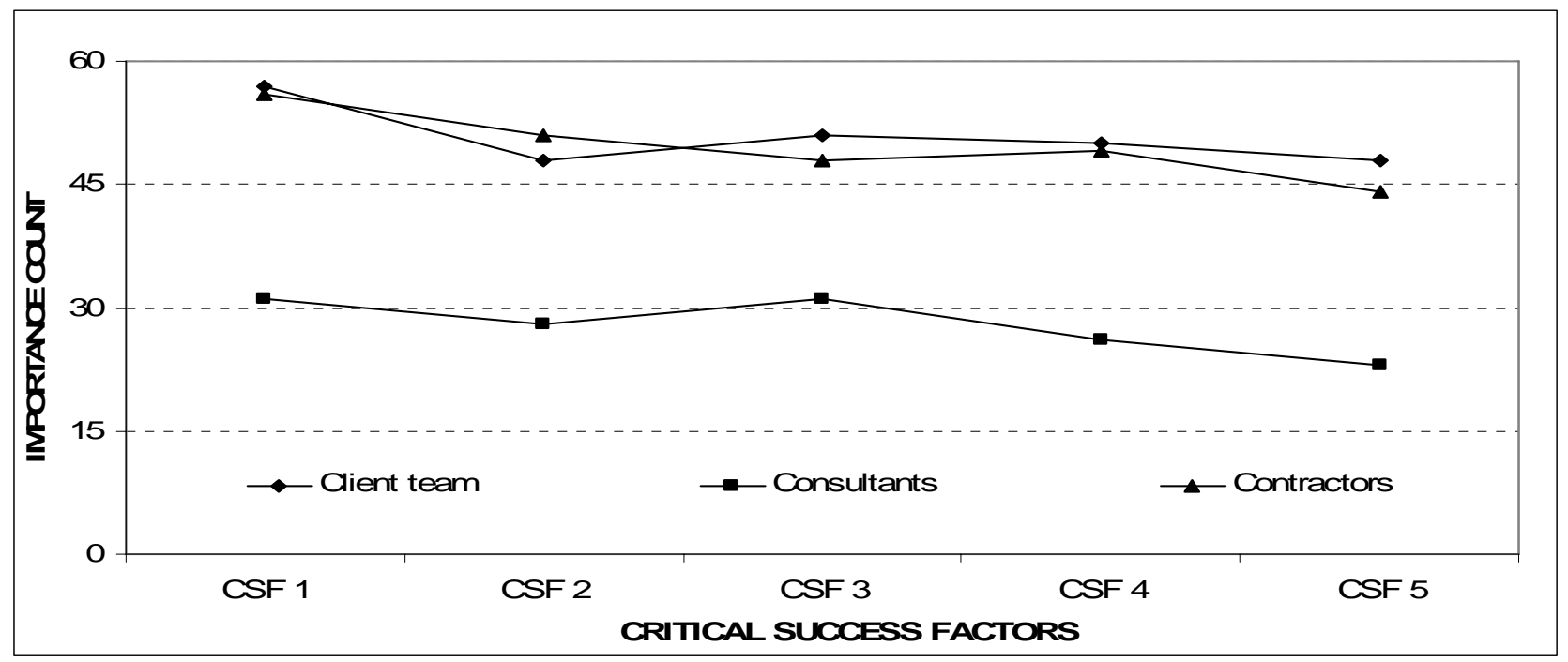

Figure 1: Importance rankings of critical success factors

\subsection{Measures of project success}

The most common measures of project success were identified from the literature review. The measures proposed by Lim and Mohamed [9] plus ten others were deemed most suitable. The selected ten measures relate either to the implementation process or to client satisfaction with the execution of the project. A survey questionnaire was used to test the perceptions of the project community with respect to the importance of each identified measure. Respondents were asked to rate the impact of each measure on both green-field and brown-field project environments. They were also required to rank the importance based on the perceived contribution of each measure towards project success. The five highest ranked were selected as the success measures for brown-field projects.

\begin{tabular}{|c|l|c|}
\hline Code & Description of success measure & $\begin{array}{c}\text { Impact } \\
\text { indicator } \\
\text { (a) }\end{array}$ \\
\hline SM 1 & It solves problem for which it was created & 121 \\
\hline SM 2 & Customer uses its end product (plant, service, etc) & 119 \\
\hline SM 3 & Customer / user is satisfied with its end product & 119 \\
\hline SM 4 & $\begin{array}{l}\text { It meets operational performance (end product } \\
\text { performs designed functions) }\end{array}$ & 117 \\
\hline SM 5 & $\begin{array}{l}\text { It meets technical specifications (end product conforms } \\
\text { to technical specifications) }\end{array}$ & 116 \\
\hline
\end{tabular}

Table 2: Identification of the success measures 
Table 2 illustrates the selection process for the success measures. Column A indicates the perceived impact of each measure on brown-field project success, combined for all respondents.

The relationship between the responses of the four stakeholder groups was investigated to establish acceptable confidence in the importance ranking for each success measure. Figure 2 shows good agreement within the client teams, but remarkable disagreement between the project and client teams over the importance rankings.

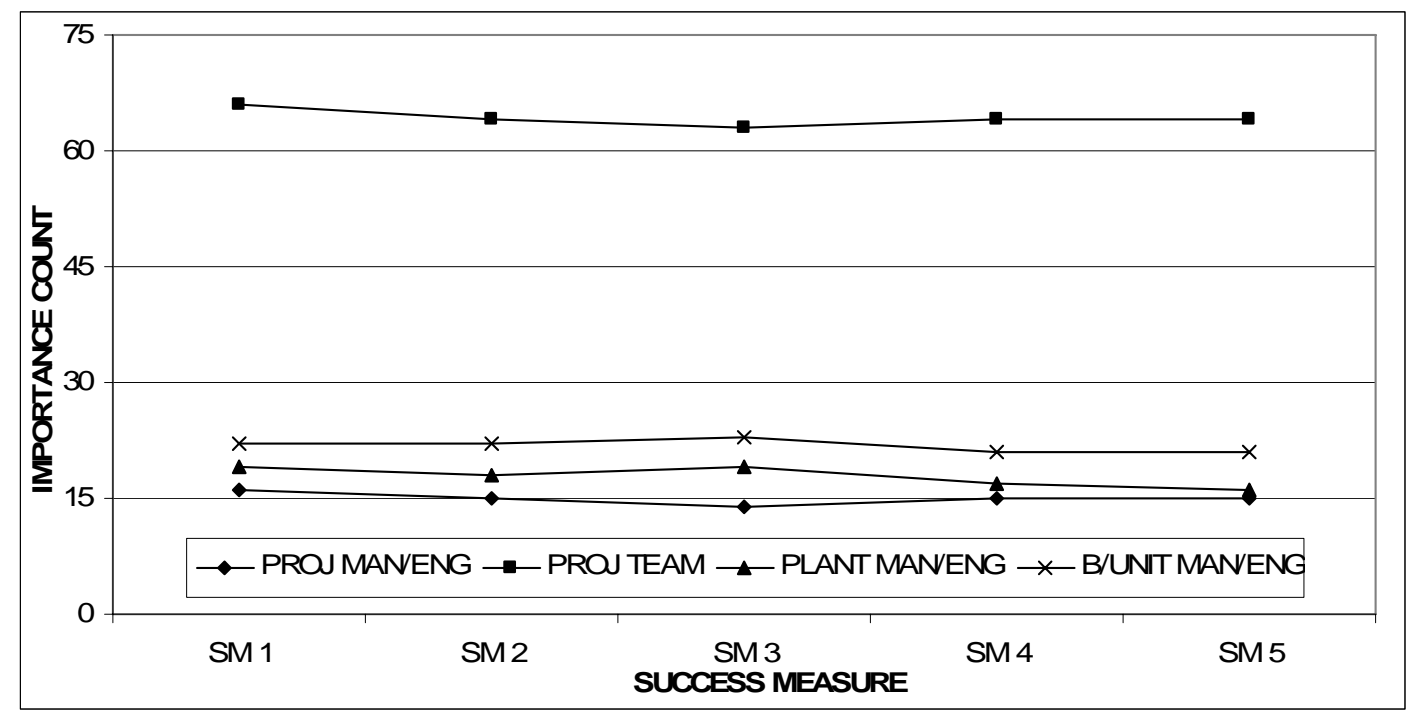

Figure 2: Importance ranking of success measures

\subsection{Relationship between critical factors and success measures}

A two-step process was applied to establish the degree of correlation between the managerial focus on critical success factors and the outcome of a project. Firstly, a suitable database of projects was examined, and ten projects were selected to cover most of the variables associated with brown-field projects. The following factors were taken into account in the selection process:

- technological advancement,

- $\quad$ project size (planned budget),

- $\quad$ access restrictions (resulting in delays and increased logistical difficulties),

- $\quad$ project duration (planned duration),

- impact of project on the existing asset (plant),

- impact of the existing asset (plant) on project, and

- $\quad$ project type.

The data was derived from an historical database of projects executed in the period 2002 to 2005. Secondly, the degree of managerial focus on critical success factors was evaluated for each project in the database. At the same time, the success of each 
project was evaluated. Finally, the relationship between the two variables was examined.

Respondents were asked to assess managerial focus on each of the five critical success factors for every project in which they had participated. Respondents were also asked to rate project success by evaluating each of the five project success measures.

The feedback from the respondents was collated per project - separately for critical factors and for success measures. This resulted in an array of $\mathrm{x}-\mathrm{y}$ parameters describing two variables: critical success factors (independent variable) and project success measures (dependent variable). The findings are represented in Figure 3, and show a reasonable correlation between the measures of success and critical factors. The correlation suggests that increased managerial focus on critical factors results in an increased chance of project success.

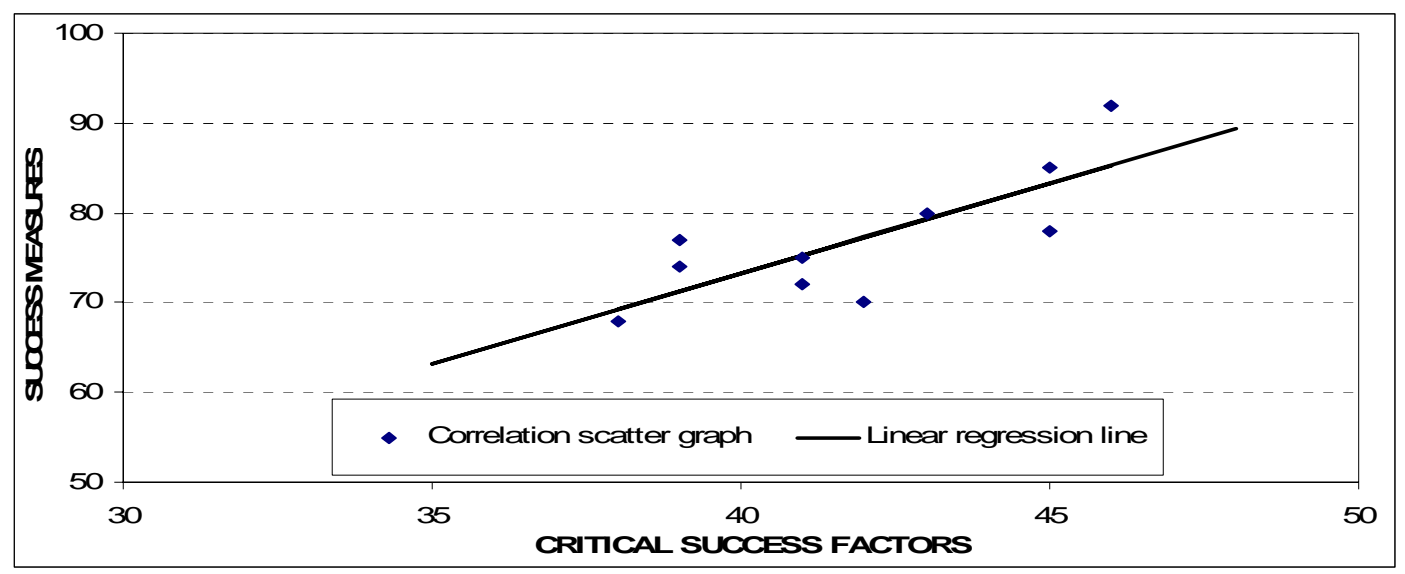

Figure 3: Relationship between brown-field CSFs and success measures

\section{SUMMARY}

For manufacturing- and processing-based businesses dependent on a large base of physical assets, brown-field capital expansion and renewal projects may provide the strategic weapon to create economic value and competitive advantage. Although each project may be a unique endeavour, the study described in this paper shows that there is a positive relationship between managerial focus on a set of critical factors and successful brown-field projects.

Although the perception of respondent groups on the importance ranking of critical factors and success measures was not the same, the indication is that the chance for success in brown-field projects may be improved by increased managerial focus on the following critical factors:

- Consultation and communication with client

- Recognising complexity

- Commitment of end user 
- Flexible approach to change

- Taking account of external influences

The results of the study imply that increased managerial efforts on the above CSFs could mean that a brown-field project will:

- meet technical specifications (end product conforms to technical specifications);

- provide an acceptable level of operational performance (end product performs designed functions);

- $\quad$ solve the problem for which it was created, and

- minimise the gap in customer expectations.

In order to improve the accuracy of the study, it is proposed that further studies be carried out using a wider study population.

\section{REFERENCES}

[1] Atkinson, R. (1999). Project management: Cost, time and quality, two best guesses and a phenomenon, it's time to accept other success criteria. International Journal of Project Management, 17(6), 337-342.

[2] Baker, B.N., Fisher, D. (1988). Factors affecting project success. In: Cleland, D.I., King, W.K. (eds) (1988). Project management handbook. New York, Van Nostrand.

[3] Belassi, W., Tukel, O.I. (1996). A new framework for determining critical success / failure factors in projects. International Journal of Project Management, 14(3), 141-151.

[4] Bloodgood, J.M., Katz, J.P. (2004). Manufacturing capacity, market share, and competitiveness. Competitiveness Review, 14(i1-2), 60-73.

[5] Cleland, D.I., King, W.R. (1983). Systems analysis and project management. McGraw-Hill, New York. In: Shenhar, A.J. (2001) One size does not fit all projects: Exploring classical contingency domains. Management Science, 47(3), 394-415.

[6] DeCotiis, T.A., Dyer, L. (1979). Defining and measuring project performance. Research Management, 16, 17-22.

[7] Dvir, D., Lipovetsky, S., Shenhar, A., Tishler, A. (1998). In search of project classification: A non-universal approach to project success factors. Research Policy, 915-935.

[8] Fondahl, J.W. (1987). The history of modern project management. Project Management Journal, 28(2), 33-36.

[9] Lim, C.S., Mohamed, M.Z. (1999). Criteria of project success: An exploratory examination. International Journal of Project Management, 17(4), 243-248.

[10] Oisen, R.P. (1971). Can project management be defined? Project Management Quarterly, 2(1), 12-14. In: Atkinson, R. (1999). Project management: Cost, time and quality, two best guesses and a phenomenon, it's time to accept other success criteria. International Journal of Project Management, 17(6), 337-342. 
[11] Pinto, J.K., Mantel, S.J.Jr. (1990). The causes of project failure. IEEE Transactions on Engineering Management, 37(4), 269-276.

[12] Pinto, J.K., Slevin, D.P. (1987). Critical factors in successful project implementation. IEEE Transactions on Engineering Management, 34(1), 2227.

[13] Rubin, I.M., Seeling, W. (1967). Experience as a factor in the selection and performance of project managers. IEEE Transactions on Engineering Management, 14(3), 131-134.

[14] Shenhar. A.J., Dvir, D., Levy, O., Maltz, A.C. (2001). Project success: A multidimensional strategic concept. Long Range Planning, 34, 699-725.

[15] Shultz, R.L., Slevin, D.P., Pinto, J.K. (1987). Strategy and tactics in a process model of project implementation. Interfaces, 17(3), 34-46.

[16] Westerveld, E. (2003). The Project Excellence Model ${ }^{\circledR}$ : Linking success criteria and critical success factors. International Journal of Project Management, 21, 411-418.

[17] White, D., Fortune, J. (2002). Current practice in project management - an empirical study. International Journal of Project Management, 20, 1-11. 